\title{
Technology, Imaging, History and Anatomy the Future of Learning Techniques
}

\author{
Gregory Tsoucalas*1, Konstantinos Laios ${ }^{2}$, Efstathia Lagiou ${ }^{3}$ and Theodoros Papaioannou ${ }^{4}$ \\ ${ }^{1}$ History of Medicine, Anatomy Department, Democritus University of Thrace, Greece \\ ${ }^{2}$ History of Medicine Medical School, National and Kapodistrian University of Athens \& Department of Surgery Konstantopouleio-Agia Olga Hospital, Greece \\ ${ }^{3}$ Medical School, Universtity of Patras, Greece \\ ${ }^{4}$ Department of Cardiology, Hippokration Hospital, National and Kapodistrian University of Athens, Greece
}

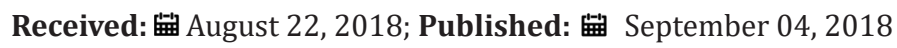

*Corresponding author: Gregory Tsoucalas, History of Medicine, Anatomy Department, Medical School, Democritus University of Thrace, Alexandroupolis, Greece

\section{Introduction}

Technology from the Greek term technologies which derives from the words "techno" meaning "art" and "logos" meaning

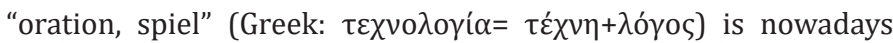
defined as "the result of theoretical knowledge in order to create objects-machines that could affect the ability of a species to control its environment and adapt to it [1]. Imaging is defined as "the visual representation of an image which is perceived by human senses or of a form-figure which could not be understood due to its spatial position" [2]. Anatomy is defined as "the medical branch that deals with the study, recording, and description of the structure of living organisms and their individual systems" [3]. The term "history"

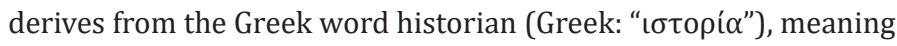
"inquiry, knowledge acquired by investigation"). History is usually defined as the study of past events, particularly in human affairs [4]. As technology succeeded to manufacture machines able to visualize in depth depictions of the human body, in the narrow area where those for different entities are meet, medical imaging, history and anatomy are being connected through technology to create both clinical and learning curves in medicine (Figure 1).

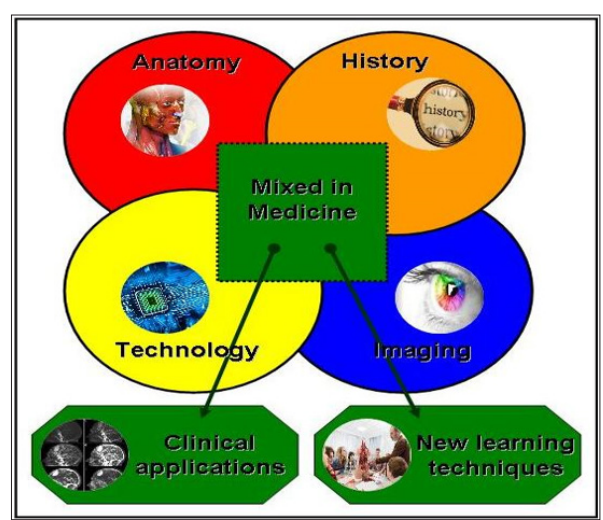

Figure 1: The relationship between anatomy, history, technology and imaging in medical science and its results, clinical applications and learning techniques.
Worldwide, human gross anatomy courses form the basis for the medical curricula, aiming to introduce the very core of anatomical concepts within the clinical context both for future and specialized physicians. A solid understanding of the human's body construction is essential for all medical specialties [5]. Although expert medical professionals consider anatomy to be the most relevant basic discipline during their daily clinical activity, students usually perceive anatomy as the more challenging subject, resulting to anxiety and learning difficulties [6-7]. New learning modalities introduced during the last decade towards the formation of a blended learning anatomy courses to help perception and understanding among students. "Blended" is the most used term considering the combination of the more traditional face-to-face or face-to-cadaver experience and technologically mediated learning [8].

Due to rapidly evolving imaging modalities such as computed tomography, magnetic resonance imaging and positron emission tomography and their combinations, radiological images of the human body are utilized almost as a routine practise during both the preclinical education and daily medical work. Understanding radiological images requires good knowledge of gross anatomy, while on the same time radiology enhances this knowledge. Studies support that blended learning is statistically significantly better than traditional learning in most domains of the educational environment and in all types of examination improving students' performance [9]. History of Anatomy and Surgery is among the teaching objects in the Hellenic Universities, an important part of the student's education, considered to be an essential course for the in depth comprehension of human anatomy. Medical Humanities present during the last decades a fundamental disciplinary among the best universities worldwide [10]. In a four-way relationship, technology and medical imaging alongside with history of anatomy endeavour to accompany gross anatomy towards a fruitful teaching modality in the near future [9]. After all, history is a projection of 
the past in the present, anatomy is a depiction while technology provides excellent images ... eventually anatomy is, in the very essence of the term, a technology, thus an oration of the art of the human body.

\section{References}

1. Liddell HG, Scott R (1980) A Greek-English Lexicon. Oxford Publication Press Oxford, USA.

2. Gibert MG (2004) The Meaning of Technology. Selected Readings from American Sources. Univ Politèc de Catalunya Barcelona

3. Gray H (1918) Anatomy of the Human Body 20th ed. Lea \& Febiger Philadelphia

4. Carr EH (1962) What Is History?: The George Macaulay Trevelyan Lectures Delivered in the University of Cambridge January-March 1961. Cambridge University Press, Cambridge.

5. Kugelmann D, Stratmann L, Nühlen N, Bork F, Hoffmann F, et al. (2018) An Augmented Reality magic mirror as additive teaching device forgross anatomy. Ann Anat 215: 71-77.

ISSN: 2574-1241

DOI: 10.26717/BJSTR.2018.08.001684

Gregory Tsoucalas. Biomed J Sci \& Tech Res

CC (P) This work is licensed under Creative

BY Commons Attribution 4.0 License

Submission Link: https://biomedres.us/submit-manuscript.php
6. Arráez Aybar LA, Sánchez Montesinos I, Mirapeix RM, Mompeo Corredera B, Sanudo Tejero JR (2010) Relevance of human anatomy in daily clinicalpractice. Ann Anat 192(6): 341-348.

7. Tsoucalas G (2018) Anatomy: An Essential Course for Future Surgeons. J Universal Surg 6(1): 8.

8. Wood BP (2011) Blended learning in medicine: trouble in paradise? Am J Roentgenol 197(3): 529.

9. Makhdoom N, Khoshhal IK, Algaidi S, Heissam K, Zolaly MA (2013) Educational Study 'Blended learning' as an effective teaching and learning strategy in clinical medicine: a comparative cross-sectional university-based study Production and hosting by Elsevier. Journal of Taibah University Medical Sciences 8(1): 12-17.

10. Crawford P, Brown B, Baker C, Tischler V, Abrams B (2015) Health Humanities. Palgrave London, UK.

$\begin{array}{ll}\begin{array}{l}\text { BIOMEDICAL } \\ \text { RESEARCHES }\end{array} & \text { Assets of Publishing with us } \\ \text { - Global archiving of articles } \\ \text { - Immediate, unrestricted online access }\end{array}$

